Microb Ecol (2003) 45:291-301

DOI: $10.1007 /$ s00248-002-2036-6 (C) 2003 Springer-Verlag New York Inc.

\title{
Incorporation of Radiolabeled Leucine into Protein to Estimate Bacterial Production in Plant Litter, Sediment, Epiphytic Biofilms, and Water Samples
}

\author{
N. Buesing, M.O. Gessner \\ Department of Limnology, Limnological Research Center, Swiss Federal Institute for Environmental Science \\ and Technology (EAWAG/ETH), 6047 Kastanienbaum, Switzerland
}

Received: 31 July 2002; Accepted: 29 November 2002; Online publication: 28 March 2003

A B S S T R A C T

The present study assessed the application of tritiated leucine incorporation into protein, as a measure of bacterial biomass production, within four benthic habitats of a littoral freshwater wetland dominated by emergent vegetation. Basic assumptions underlying the method, such as linearity of leucine incorporation, saturation level of incorporation rates, and specificity of incorporation for bacterial assemblages, were tested, and two procedures for extracting radiolabeled protein were compared. TCA precipitation followed by ultrasonication, and subsequent alkaline dissolution in $0.5 \mathrm{M} \mathrm{NaOH}, 25 \mathrm{mM}$ EDTA, and $0.1 \% \mathrm{w} / \mathrm{v}$ SDS, gave best results in terms of both extraction efficiency and signal-to-noise ratio. Incorporation of leucine was linear for all habitats for up to $1 \mathrm{~h}$. Saturation concentrations of leucine incorporation into protein were 150 $\mathrm{nM}$ for littoral surface waters, $>960 \mathrm{nM}$ for biofilms on plant surfaces, and $50 \mu \mathrm{M}$ for aerobic sediment and submerged plant litter. An experiment with prokaryotic and eukaryotic inhibitors designed to examine specificity of leucine incorporation into bacterial protein showed no significant leucine incorporation into eukaryotes during short-term incubations. Calculations based on kinetic parameters of fungal leucine uptake suggest, nevertheless, that significant leucine incorporation cannot be ruled out in all situations. Thus, the leucine methodology can be used for estimating bacterial production in benthic aquatic habitats, provided that substrate saturation and isotope dilution are determined and that the active biomass of eukaryotes, such as fungi, does not greatly exceed bacterial biomass.

\section{Introduction}

Determining bacterial production is important for quantifying the contribution of bacteria to carbon cycling in Present address: (Nanna Buesing) Limnologische Flusstation, MaxPlanck-Institut für Limnologie, Postfach 260, 36105 Schlitz, Germany Correspondence to: N. Buesing; E-mail: nbuesing@mpil-schlitz.mpg.de ecosystems [1,39]. Various methods have been proposed to this end; the two most commonly accepted and widely used ones consist in monitoring the incorporation of radiotracers (e.g., $[3 \mathrm{H}]$ thymidine, $[3 \mathrm{H}]$ or $[14 \mathrm{C}]$ leucine) into cellular macromolecules (DNA and proteins, respectively) during short-term incubations [32, 33, 8]. Critical assumptions underlying this approach include (i) linearity 
of precursor incorporation during incubations, which would indicate a lack of shifts in bacterial metabolism during experimental incubations; (ii) assurance that incorporation is measured at precursor concentrations that maximize incorporation rates (substrate saturation); (iii) efficient and reproducible extraction of radiolabeled macromolecules from incubated samples; and (iv) restriction of macromolecule labeling to bacterial assemblages (specificity). The thymidine and leucine method was originally developed for estimating bacterioplankton production in the ocean $[12,18,38]$; only minimal adjustments were needed to adapt it to measuring production of pelagic bacteria in lakes (e.g., [16, 29]). However, some of the assumptions above are not always met in environments such as sediments $[42,10,19]$, soils $[25,3]$, biofilms [41, 11], or decaying plant litter [44], suggesting that procedures used routinely in pelagic environments need to be adapted to determine bacterial production in these habitats.

In marine waters, saturation of leucine incorporation rates typically occurs at concentrations of 10-20 nM [38, 9]. Higher concentrations (up to $100 \mathrm{nM}$ ) are needed in pelagic freshwater systems [16], but these are still well below half-saturation constants $\left(K_{t}\right)$ for leucine uptake by eukaryotes [15], suggesting that notable leucine incorporation into protein is restricted to bacteria, at least during short-term (<60 $\mathrm{min})$ incubations. However, in some benthic habitats, saturation of leucine incorporation has been reported to occur only at concentrations three orders of magnitude higher $[17,23,10]$. A potentially serious shortcoming when working in systems requiring leucine concentrations in the micromolar range is, therefore, that incorporation into protein may not be restricted to bacterial assemblages.

In the original description of the method, Kirchman et al. [18] extracted radiolabeled protein with hot TCA [27, 36]. Another efficient extractant for protein is alkaline solution [35,30], prompting several investigators to include a $\mathrm{NaOH}$ extraction step in their protocol. Meyer-Reil and Charfreitag [24], Marxsen [23], and Kirschner and Velimirov [19] first extract protein with alkaline solution before precipitating with TCA. Kirschner and Velimirov [20], Bååth et al. [3], and Suberkropp (pers. comm.) reversed the order by stopping the incubation of radiolabel with TCA and subsequently extracting protein with alkaline solution, after removal of unincorporated radiolabel. Both approaches present theoretical advantages and disadvantages, but since empirical comparisons have not been made, their relative performance in practice is unknown.

Apart from efficient extraction, an important criterion for selecting a specific method is the signal-to-noise ratio, which can be negatively affected either by nonspecific incorporation of radiolabeled leucine into molecules other than protein or by adsorption of radiolabel (or any extracellular transformation products) to the sample matrix. Nonspecific incorporation of radiolabeled leucine into other macromolecules has been found to be minor; leucine is efficiently ( $>90 \%$ ) incorporated into protein [32], which is the only fraction that becomes significantly radiolabeled $[7,45,31]$. However, high background values have been observed in control treatments of sediment samples in which bacteria were killed before radioactivity was added [13], suggesting that considerable adsorption can take place when sample matrices are complex. This problem is likely to compromise accurate determination of bacterial production, particularly with highly organic samples such as plant litter.

The present study was conducted to test key assumptions underlying the leucine incorporation method for bacterial assemblages in various freshwater habitats, some of which have not been well studied and bear the risk of introducing artifacts in bacterial production estimates. Specifically, we tested the specificity of leucine incorporation into the protein fraction of bacteria associated with plant litter and sediment in an experiment using prokaryotic and eukaryotic inhibitors. In addition, we examined the linearity of leucine incorporation and substrate saturation for bacteria in submerged plant litter, sediment, biofilms on plant surfaces, and littoral surface water of a lake. Isotope dilution was also assessed. Finally, we compared two procedures for extracting radiolabeled protein from plant litter and sediment samples with alkaline solution in attempt to optimize extraction efficiency and to lower the notoriously high signal-to-noise ratios encountered with this type of samples.

\section{Materials and Methods}

\section{Sample Collection}

Samples were collected in a littoral stand of the common reed, Phragmites australis (Cav.) Trin. ex Steud., situated on the eastern shore of Lake Hallwil $\left(47^{\circ} 17^{\prime} \mathrm{N}, 8^{\circ} 14^{\prime} \mathrm{E}\right)$, a eutrophic hardwater lake in central Switzerland [34]. Depth-integrated water samples were taken and placed in acid-washed glass bottles. Submerged standing portions of reed culms with attached 
epiphyton were clipped just above the sediment surface, cut into $10-\mathrm{cm}$ pieces, and placed into sterile $50-\mathrm{mL}$ centrifuge tubes containing lake water. Sediment was sampled with a hand-held corer (6 $\mathrm{cm}$ in diameter) and the top layer was removed for experiments. Submerged decaying plant litter was collected by hand from the sediment surface and placed into clean plastic boxes. Samples were kept cool in an ice chest during transport to the laboratory.

\section{Experiment I: Substrate Saturation and Isotope Dilution}

Constant amounts of L-[4, 5- $\left.{ }^{3} \mathrm{H}\right]$ leucine (TRK170, Amersham, Buckinghamshire, UK) with a specific activity of $5.03 \mathrm{TBq}$ $\mathrm{mmol}^{-1}$ and increasing amounts of unlabeled L-leucine (Fluka, Buchs, Switzerland) were used to establish saturation curves of leucine incorporation into protein of the four types of collected samples. Water samples were incubated at six concentrations ranging from 15 to $480 \mathrm{nM}$ (specific activity: 0.09-2.96 TBq $\mathrm{mmol}^{-1}$ ). Epiphytic biofilm samples were incubated at seven concentrations ranging from 15 to $960 \mathrm{nM}$ (specific activity: 0.05-2.96 TBq $\mathrm{mmol}^{-1}$ ), and plant litter and sediment at six concentrations ranging from 0.01 to $50 \mu \mathrm{M}$ (specific activity: 0.52 $\mathrm{GBq}^{\mathrm{mmol}}{ }^{-1}-5.0 \mathrm{TBq}^{\mathrm{mmol}}{ }^{-1}$ ). Three replicates and one control were used at each concentration. Controls received buffered $(0.1 \% \mathrm{w} / \mathrm{v}$ sodium pyrophosphate) formalin to a final concentration of $2 \% \mathrm{v} / \mathrm{v}$ before tritiated leucine was added. Leucine solutions were prepared with $0.2-\mu \mathrm{m}$ filtered lake water. The final incubation volume of water and epiphyton samples (three $1-\mathrm{cm}$ culm pieces, $0.50 \pm 0.05 \mathrm{mg} \mathrm{C}_{\text {org }} \mathrm{cm}^{-2}$, mean $\pm 1 \mathrm{SE}$ ) was $3 \mathrm{~mL}$. Sediment slurry $\left(0.5 \mathrm{~mL}, 1.9 \pm 0.1 \mathrm{mg} \mathrm{C}_{\text {org }} \mathrm{cm}^{-3}\right)$ and plant litter (5 leaf disks, $5.5 \mathrm{~mm}$ diameter, $2.2 \pm 0.3 \mathrm{mg} \mathrm{Corg}$ ) were incubated in a total volume of $1 \mathrm{~mL}$. Incubations were carried out at ambient lake temperature.

Incubations were stopped with trichloroacetic acid (TCA), precipitated proteins cleaned by multiple centrifugation and washing steps, dissolved in alkaline solution (see details below), and a $100-\mu \mathrm{L}$ aliquot added to $10 \mathrm{~mL}$ Hionic-Fluor (Packard Bioscience, Meriden, CT, USA). Radioactivity was measured with a liquid scintillation counter (Packard Tri-Carb 1600CA) and counts per minute (CPM) converted to disintegrations per minute (DPM) with appropriate quench curves established separately for each of the investigated substrates.

Incorporation rates of leucine into protein were iteratively fitted to the hyperbolic function of Michaelis-Menten-type kinetics using nonlinear regression analysis (OriginPro 6.0, Microcal Software Inc., Northampton, MA). The fitted parameters were used as estimates of maximum leucine incorporation rates $\left(v_{\max }\right)$ and half-saturation constants plus natural leucine concentrations $\left(K_{t}+S_{\mathrm{n}}\right)$ as a measure of substrate affinity. Isotope dilution was assessed as the ratio of $v_{\max }$ to $v_{\text {measured }}$ at the concentration where saturation was virtually reached [43].

\section{Experiment 2: Linearity of $\left[{ }^{3} \mathrm{H}\right]$ Leucine Incorporation}

Time course experiments were conducted at concentrations that maximized leucine incorporation, as determined in experiment 1 .
Triplicate samples of water, epiphyton, plant litter, and sediment were incubated at five time intervals ranging from 0 to $90 \mathrm{~min}$. Triplicate samples and one formalin-treated control were incubated and analyzed as in experiment 1 . Linear regressions were calculated based on individual data points.

\section{Experiment 3: Prokaryotic versus Eukaryotic Leucine Incorporation}

Prokaryotic and eukaryotic selective inhibitors were used to examine the potential for eukaryotic incorporation of leucine at high concentrations. The eukaryotic inhibitors cycloheximide $(0.02 \%)$ and colchicine $(0.01 \%)$ were used to inhibit fungi and other eukaryotes $[37,28]$, whereas chloramphenicol $(0.001 \%)$ and streptomycin $(0.1 \%)$ were used to inhibit bacteria [22]. Cycloheximide, chloramphenicol, and streptomycin interfere with protein synthesis, whereas colchicine depolymerizes microtubules in dividing eukaryotic cells. Submerged decaying leaf litter of $P$. australis was used in this experiment, since this material is known to be colonized by fungi [21]. Four treatments were examined: (a) no addition of inhibitors, (b) addition of eukaryotic inhibitors, (c) addition of bacterial inhibitors, (d) addition of both types of inhibitors. Triplicate samples of five leaf disks each (diameter $5.5 \mathrm{~mm}$ ) were incubated at leucine concentrations of $0.02,0.4$, and $50 \mu \mathrm{M}$ (specific activity of $2.36 \times 10^{6}, 1.18 \times 10^{11}$, and $9.46 \times 10^{8} \mathrm{~Bq} \mathrm{mmol}{ }^{-1}$, respectively). These concentrations were chosen to reflect the full range of concentrations used previously for estimating bacterial production associated with large organic particles in freshwaters [26, 41, 40,19]. Incubations were stopped by the addition of trichloroacetic acid (TCA) to a final concentration of $5 \%$. Labeled protein was extracted in alkaline solution and a $100-\mu \mathrm{L}$ aliquot of the extract was radioassayed (see details below).

\section{Experiment 4: Efficiency of Protein Extraction}

The efficiency of two procedures was tested for extracting radiolabeled protein from sediment and plant litter samples. Eight replicates of $0.5-\mathrm{mL}$ sediment slurry or 5 disks (diameter $5.5 \mathrm{~mm}$ ) from decaying leaf were incubated in a total volume of $1 \mathrm{~mL}$ of a $\left[{ }^{3} \mathrm{H}\right]$ leucine solution with a specific activity of $1.04 \mathrm{~Bq} \mathrm{mmol}{ }^{-1}$ and a total added leucine concentration of 50 $\mu \mathrm{M}$. In extraction method 1 , macromolecules (proteins and nucleic acids) were first precipitated with TCA and carried through a series of cleaning steps before radiolabeled protein was dissolved in alkaline solution and radioassayed $[20,3]$. In method 2, proteins were immediately extracted with alkaline solution, then carried through several cleaning steps, precipitated with TCA, redissolved in $\mathrm{NaOH}$, and radioassayed [24, 23, 19]. In extraction method 1 , the incorporation of $\left[{ }^{3} \mathrm{H}\right]$ leucine was terminated by adding TCA to a final concentration of $5 \%$. Samples were placed on ice for $20 \mathrm{~min}$ to precipitate macromolecules, and then centrifuged for $10 \mathrm{~min}$ at $14,000 \mathrm{~g}$. The supernatants were discarded and the pellets washed 
once each with $1 \mathrm{~mL}$ of $5 \%$ TCA, $80 \%$ ethanol, and nanopure water, each time alternating with a $10-\mathrm{min}$ centrifugation step as above. Macromolecules were then dissolved in alkaline solution $\left(0.5 \mathrm{~N} \mathrm{NaOH}, 25 \mathrm{mM}\right.$ EDTA, and $0.1 \% \mathrm{SDS}$ ) for $60 \mathrm{~min}$ at $90^{\circ} \mathrm{C}$ in a dry bath. Samples were cooled to ambient temperature, and a $100-\mu \mathrm{L}$ aliquot mixed with $10 \mathrm{~mL}$ Hionic-Fluor (Packard Bioscience, Meriden, USA) and radioactivity measured with a Packard Tri-Carb 1600CA liquid scintillation counter. Quench curves for sediments and leaf litter were previously established by adding increasing amounts of unlabeled extract to a known amount of radioactivity. tSIE (transformed spectral index of the external standard) values were plotted against the counting efficiency and the resulting quench curve was used for converting CPM into DPM.

In extraction method $2,\left[{ }^{3} \mathrm{H}\right]$ leucine incorporation was stopped by adding $0.5 \mathrm{M} \mathrm{NaOH}$. Macromolecules were extracted in alkaline solution ( $0.5 \mathrm{M} \mathrm{NaOH}, 25 \mathrm{mM}$ EDTA, and $0.1 \% \mathrm{SDS}$ ) for $60 \mathrm{~min}$ at $90^{\circ} \mathrm{C}$ as in method 1 above. Samples were then placed on ice, neutralized with $10 \mu \mathrm{L}$ of $5 \mathrm{M} \mathrm{HCl}$, and macromolecules precipitated with TCA ( $5 \% \mathrm{w} / \mathrm{v}$ final concentration). Samples were centrifuged for $10 \mathrm{~min}$ at $14,000 \mathrm{~g}$ and supernatants discarded. The pellets were washed once with $1 \mathrm{~mL} 5 \%$ TCA, 80\% ethanol, and nanopure water as in method 1. Macromolecules were solubilized in $0.5 \mathrm{M} \mathrm{NaOH}$ at $90^{\circ} \mathrm{C}$ for $30 \mathrm{~min}$ and a $100-\mu \mathrm{L}$ aliquot of the solution was radioassayed.

\section{Experiment 5: Improvement of Sample-to-Blank Ratios}

To test whether ultrasonic treatment would improve the sampleto-blank ratio in leucine incorporation measurements, both sediment and litter samples were treated for $1 \mathrm{~min}$ with an ultrasonic probe (Branson Sonifier 250, output $80 \mathrm{~W}$, amplitude 76 $\mu \mathrm{m}$; see [6]) before TCA precipitation and compared to untreated samples. Eighteen replicate samples were used for each substratum. Results were compared with a paired $t$-test.

\section{Experiment 6: $\left[{ }^{3} \mathrm{H}\right]$ Leucine Incorporation into Nucleic Acids}

An additional experiment was conducted to establish whether tritiated leucine is incorporated into macromolecules other than protein. According to Schneider [36], hot TCA extraction separates RNA and DNA from the protein fraction. If significant amounts of radiolabel were incorporated into DNA, boiling in TCA should result in lower radioactive counts than a treatment with cold TCA. To test whether a separation of the nucleic acid and protein fraction is necessary, three sediment samples $(0.5 \mathrm{~mL}$ slurries, $\left.16 \mathrm{mg} \mathrm{C}_{\text {org }}\right)$ and three submerged plant litter samples (80 mg wet weight, $7 \mathrm{mg} \mathrm{C}_{\text {org }}$ ) were incubated and extracted according to method 1 described above. Parallel sets of samples were extracted for $60 \mathrm{~min}$ at $90^{\circ} \mathrm{C}$ in $5 \% \mathrm{TCA}$ and subsequently cooled to ambient temperature. After centrifugation (10 min at $14,000 \mathrm{~g}$ ), the supernatant containing nucleic acids was discarded and the pellet containing radiolabeled proteins dissolved in alkaline solution and radioassayed.

\section{Results}

\section{Experiment I: Substrate Saturation and Isotope Dilution}

Saturation of leucine incorporation rates into protein occurred at vastly different concentrations for the four substrates examined (Fig. 1a-d), at $120 \mathrm{nM}$ with littoral water, >960 nM with epiphyton, and $50 \mu \mathrm{M}$ with both sediment and plant litter. Considerable variability among replicates was observed at higher concentrations, most likely resulting from the lower specific activity of leucine added to those samples.

Isotope dilution estimated as the ratio of $v_{\max }$ to $v_{\text {measured }}$ ranged from 1.15 in sediment samples to 1.31 in epiphyton samples (Table 1). Half-saturation constants plus the natural leucine concentrations $\left(K_{t}+S_{\mathrm{n}}\right)$ ranged from $30 \mathrm{nM}$ in littoral water samples to $10.9 \mu \mathrm{M}$ in plant litter samples (Table 1).

\section{Experiment 2: Linearity of $\left[{ }^{3} \mathrm{H}\right]$ Leucine Incorporation}

Incorporation of leucine was linear for up to $60 \mathrm{~min}$ for all substrates tested (Fig. 1e-h). At longer incubation times, incorporation tended to level off in water, sediment, and plant litter samples, but remained linear for up to $90 \mathrm{~min}$ in epiphyton samples.

\section{Experiment 3: Prokaryotic versus Eukaryotic Leucine Incorporation}

In the absence of bacterial and fungal inhibitors, incorporation rates of leucine into protein increased with increasing concentrations of added leucine (Fig. 2a), confirming the observation of experiment 1 that micromolar leucine concentrations are required to achieve saturation with plant litter (Fig. 1d). Addition of antibacterial compounds reduced incorporation of leucine to background levels at all concentrations tested, irrespective of whether prokaryotic inhibitors were given alone (Fig. 2c) or in combination with eukaryotic inhibitors (Fig. 2d). When samples were treated with fungal inhibitors alone, no decrease in incorporation rates was observed at concentrations in the nanomolar range. At 50 $\mu \mathrm{M}$, incorporation was $28 \%$ lower compared to the treatment with no inhibitors (Figs. 2a, b). However, the fact that neither the inhibitor effect (two-way ANOVA, $p=0.99$; $t$-test, $p=0.46$, for $50 \mu \mathrm{M}$ only) nor the interaction of treatment type (i.e., no inhibitors vs eukaryotic 

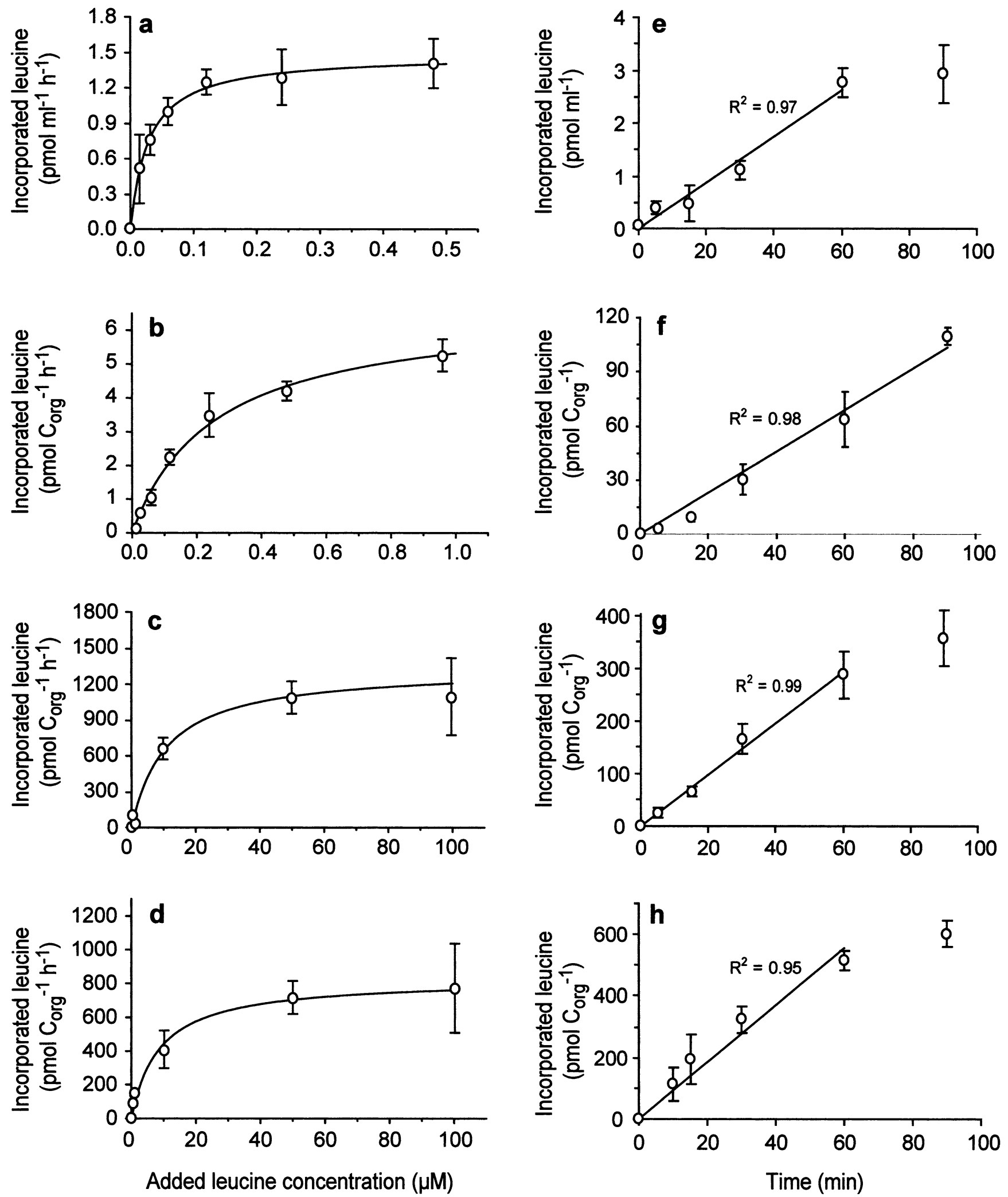

Fig. 1. Substrate saturation curves of leucine incorporation into protein with littoral water samples (a), epiphytic biofilms on submerged reed culms (b), submerged plant litter (c), and aerobic sediment (d), and corresponding time series of leucine incorporation (e-h). Symbols are means of three replicate measurements. 
Table 1. Measured $\left(v_{\text {meas }}\right)$ and maximum $\left(v_{\max }\right)$ rates of leucine incorporation into protein, isotope dilution, and half-saturation constants $\left(K_{t}\right.$ plus the natural leucine concentration, $\left.S_{\mathrm{n}}\right)$ determined in saturation experiments and calculated by nonlinear curve-fitting to Michaelis-Menten-type kinetics

\begin{tabular}{lccccc}
\hline Substrate & $v_{\text {meas }}^{\mathrm{a}}$ & $v^{\mathrm{a}}{ }_{\max }$ & Isotope dilution $^{\mathrm{b}}$ & $K_{t}+S_{\mathrm{n}}(\mu \mathrm{M})$ & $r^{2}$ \\
\hline Sediment & $716 \pm 60$ & $825 \pm 110$ & $1.15 \pm 0.18$ & $8.7 \pm 3.9$ & 0.95 \\
Plant litter & $1090 \pm 241$ & $1340 \pm 80$ & $1.23 \pm 0.28$ & $10.9 \pm 2.2$ & 0.99 \\
Epiphyton & $5.1 \pm 0.8$ & $6.7 \pm 0.8$ & $1.31 \pm 0.26$ & $0.26 \pm 0.06$ & 0.98 \\
Water & $1.3 \pm 0.1$ & $1.48 \pm 0.03$ & $1.17 \pm 0.09$ & $0.029 \pm 0.002$ & 0.99 \\
\hline
\end{tabular}

Values are means of three replicates $\pm 1 \mathrm{SE}$.

${ }^{a}$ pmol $\mathrm{mg}^{-1} \mathrm{C}_{\text {org }} \mathrm{h}^{-1}$ for sediment, plant litter, and epiphyton and $\mathrm{pmol} \mathrm{mL}^{-1} \mathrm{~h}^{-1}$ for water samples.

b Ratio of $v_{\text {max }}$ to $v_{\text {measured; }} \mathrm{SE}$ calculated using error propagation rules.

inhibitors) $\times$ leucine concentration (two-way ANOVA, $p=0.44)$ was significant indicates that the observed decrease at $50 \mu \mathrm{M}$ was within the variability range of replicate samples.

\section{Experiment 4: Efficiency of Protein Extraction}

Extraction method 1 resulted in significantly higher incorporation rates into protein than method 2 with both sediment $(2.1 \times$ higher $)$ and plant litter samples $(6.3 \times$ higher) (Table 2). In addition, the sample-to-blank ratio was considerably higher with Method 1 , even when expressed in relative terms (Table 2).

\section{Experiment 5: Effect of Ultrasonic Treatment on the Sample-to-Blank Ratio}

The ratio of radioactivity determined in samples and formalin-treated controls increased significantly when plant litter and sediment were treated with an ultrasonic probe for $1 \mathrm{~min}$ before precipitating macromolecules with TCA. With sediment, control values were reduced sixfold from $21 \pm 2 \% \quad$ (mean \pm 1 SE) without treatment to $3.6 \pm 0.3 \%$ after ultrasonication. Controls for plant litter were reduced threefold from a high of $79 \pm 4 \%$ without ultrasonication to $26 \pm 4 \%$ when subjected to ultrasonic treatment.

\section{Experiment 6: $\left[{ }^{3} \mathrm{H}\right]$ Leucine Incorporation in Nucleic Acids}

There was no significant difference in protein extraction efficiencies whether proteins were treated with hot or cold TCA (Table 3) before extraction in alkaline solution. Consequently, it is unlikely that significant amounts of radiolabel were incorporated into DNA.

\section{Proposed Extraction Protocol}

Based on the results of the above experiments, the following protocol for extracting protein from radiolabeled microbial cells is proposed (Fig. 3). Incorporation of leucine is stopped by adding TCA to a final concentration of $5 \% \mathrm{w} / \mathrm{v}$. Samples are then sonified for $1 \mathrm{~min}$ and centrifuged for $10 \mathrm{~min}$ at $14,000 \mathrm{~g}$. The supernatant is removed from the sample and filtered over $0.2-\mu \mathrm{m}$ polycarbonate filter supported by a backing filter. Both filter and pellet are washed twice with 5\% TCA, once with $40 \mathrm{mM}$ leucine, once with $80 \%$ ethanol, and once with nanopure water. The filter and pellet are combined in a centrifuge tube and protein is dissolved in an alkaline solution $(0.5 \mathrm{~N} \mathrm{NaOH}$, $25 \mathrm{mM}$ EDTA, $0.1 \% \mathrm{SDS}$ ) for $60 \mathrm{~min}$ at $90^{\circ} \mathrm{C}$. The samples are cooled down to ambient temperature, centrifuged (10 min at $14,000 \mathrm{~g}$ ) and an aliquot of $100-500 \mu \mathrm{L}$, depending on expected radioactivity, is radioassayed.

\section{Discussion}

Efficient extraction of radiolabeled protein is critical when deriving bacterial production from leucine incorporation rates. Inclusion of an $\mathrm{NaOH}$ extraction step can significantly enhance extraction efficiency [20,3, Suberkropp, pers. comm.). The results of the present study indicate that this $\mathrm{NaOH}$ extraction is best carried out once unincorporated label has been removed from samples (method 1), probably as a result of both more complete extraction and reduced losses during protein cleanup steps. In addition to increasing protein extraction efficiency, the proposed procedure improves the sample-to-blank ratio with both sediment and plant litter samples. Enhanced sample-toblank ratios were accomplished by introducing an ultrasonication step to disperse organic and inorganic debris 

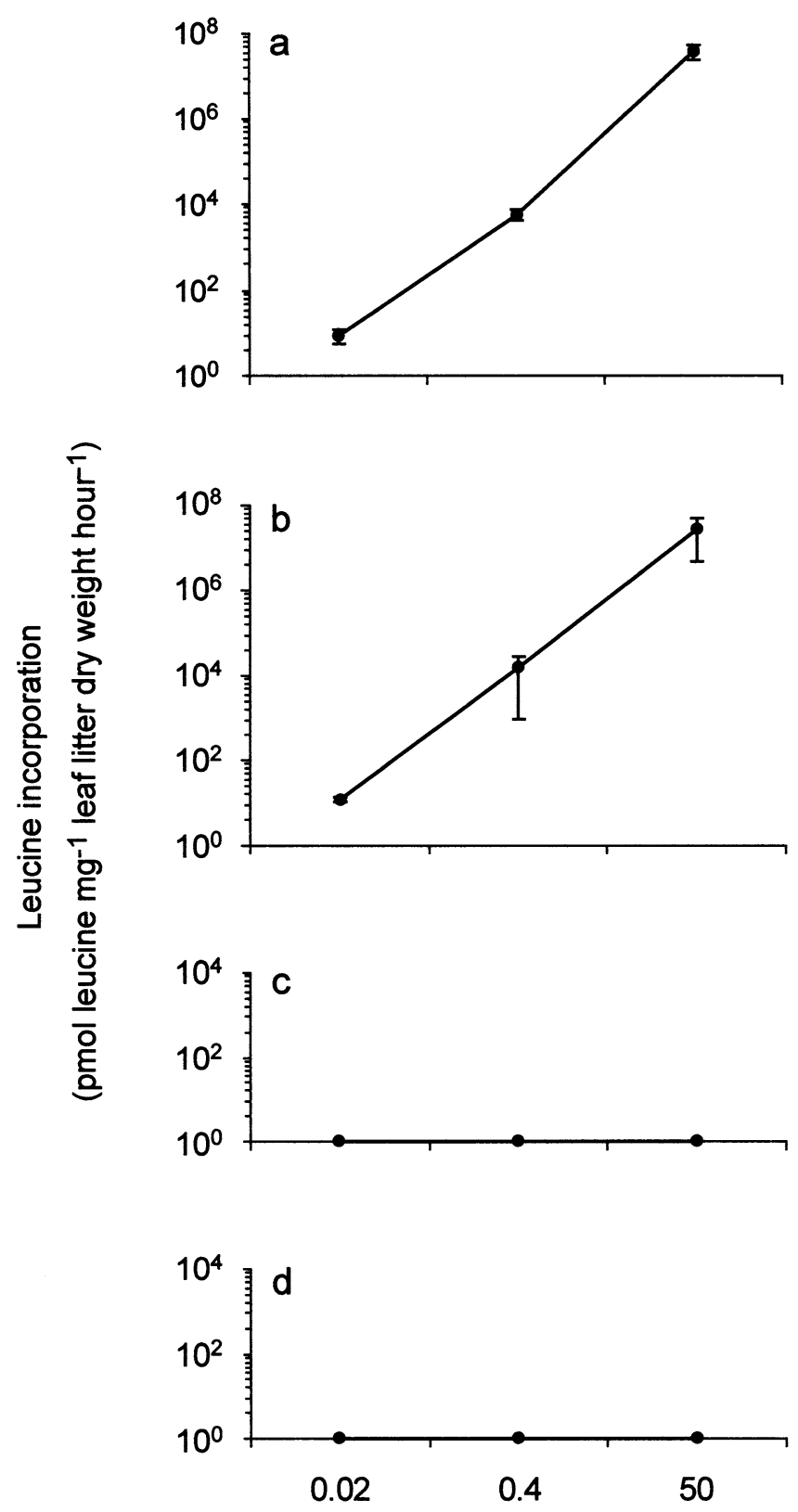

Added leucine concentration $(\mu \mathrm{M})$

Fig. 2. Rates of leucine incorporation in plant litter samples during 30-min incubations in the presence or absence of eukaryotic and prokaryotic inhibitors: (a) without inhibitors, (b) eukaryotic inhibitors only $(0.02 \%$ cycloheximide and $0.01 \%$ colchicine), (c) prokaryotic inhibitors only $(0.001 \%$ chloramphenicol and $0.1 \%$ streptomycin), (d) both types of inhibitors. Symbols are means of three replicates $\pm 1 \mathrm{SE}$; when error bars are not visible, they are smaller than symbols.

[41], coupled with abundant washing of samples in the extraction tubes before extracting in alkaline solution. These procedures resulted in fully satisfactory signal-tonoise ratios $(>10)$ with our sediment samples, although further improvement would be desirable for plant litter samples.

Treatment with hot TCA to separate nucleic acids from the insoluble protein fraction [36] proved to be unnecessary, since leucine incorporation rates of samples treated with either cold or hot TCA were not significantly different. This observation held true for both sediment and plant litter and confirms findings obtained with marine water samples [7, 45], lake water [16], and stream sediments [23].

The linear rates of leucine incorporation into protein for up to $60 \mathrm{~min}$ indicate that bacterial protein synthesis was not stimulated during short-term incubations. Incubation times of $30 \mathrm{~min}$ would thus be appropriate for estimating in-situ production rates of bacteria associated with a range of substrates encountered in freshwater wetlands, as has been found in other temperate aquatic environments [29]. However, slight deviation from linearity after $90 \mathrm{~min}$ for three of the four sample types tested indicates that bacteria may indeed shift their metabolism during prolonged incubations. Consequently, caution is needed when choosing standard incubation times greater than $1 \mathrm{~h}$ for routine measurements [16].

A significant result of the present study is that the kinetics of leucine incorporation may vary substantially among bacterial assemblages in different aquatic habitats even at a single location (Table 1 ). The divergence of $v_{\max }$ and $K_{\mathrm{t}}$ may be related to differences in both bacterial community structure and physiological adaptation to varying nutrient availability [16]; however, which of these factors predominates cannot be decided until the assemblages have been characterized taxonomically. In general, substrate saturation in the present study was found at concentrations similar to or slightly higher than those reported in other investigations. In littoral water and epiphytic biofilms, substrate saturation occurred at higher levels than in most pelagic freshwater systems, but with about $150 \mathrm{nM}$ and $1 \mu \mathrm{M}$, respectively, concentrations were still within the range observed for these types of habitats in other nutrient-rich systems [10]. Sediment samples showed the highest saturation levels, which is consistent with results from other environments, and so is the high concentration in the micromolar range needed to reach saturation [23, 10; see also 19]. Fifty $\mu \mathrm{M}$ was also required to reach saturation with plant litter, a concentration 100 fold higher than found with decaying leaves in a stream (400 nM; [40]). However, because the leucine method has only rarely been used with plant litter, it is premature to 
Table 2. Efficiency of two procedures for extracting radiolabeled protein from sediment and plant litter samples ${ }^{\mathrm{a}}$

\begin{tabular}{|c|c|c|c|c|}
\hline \multirow[b]{2}{*}{ Material } & \multirow[b]{2}{*}{ Extraction method } & \multicolumn{2}{|c|}{$\begin{array}{l}\text { Leucine incorporation rate } \\
\qquad\left(\mathrm{nmol} \mathrm{mg} \mathrm{mo}^{-1} \mathrm{C}_{\text {org }} \mathrm{h}^{-1}\right)\end{array}$} & \multirow[b]{2}{*}{ Control (\% of sample) } \\
\hline & & Sample & Control & \\
\hline \multirow[t]{2}{*}{ Sediment } & 1 & $9.1 \pm 0.2$ & 0.1 & 1.1 \\
\hline & 2 & $4.3 \pm 0.1$ & 0.8 & 18.6 \\
\hline \multirow[t]{2}{*}{ Plant litter } & 1 & $7.5 \pm 0.7$ & 0.1 & 1.3 \\
\hline & 2 & $1.2 \pm 0.3$ & 0.7 & 58.3 \\
\hline
\end{tabular}

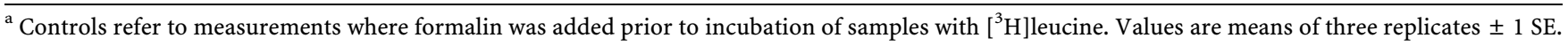
Differences between methods were significant at $p<0.001$ for both sediment and plant litter.

evaluate whether the difference with the study by Suberkropp and Weyers [40] is due to intrinsic differences between habitats (deciduous tree leaves in streams vs emergent-macrophyte tissue in freshwater wetlands) or differences in the extraction procedures.

Results obtained in this investigation support the contention that incorporation of radiolabeled leucine into protein was mainly due to bacterial metabolism, even at the leucine concentration of $50 \mu \mathrm{M}$ that was required for sediment and plant litter. This conclusion is mainly supported by the observation that addition of prokaryotic inhibitors to samples reduced incorporation rates to background levels. In addition, the eukaryotic inhibitors cycloheximide and colchicine did not exert nontarget effects on bacterial assemblages, as indicated by unchanged incorporation rates at 20 and $400 \mathrm{nM}$ of added leucine compared to samples that did not receive inhibitors. The observed reduction of leucine incorporation rates at $50 \mu \mathrm{M}$ suggests that eukaryotes could contribute to leucine incorporation into protein at this higher concentration. However, the reduction was not significant and is also counter to the total suppression of leucine incorporation observed when bacterial inhibitors were added. It is more likely, therefore, that the apparent reduction was an effect of the high variability among samples, caused by the relatively low specific activity and hence low amounts of

Table 3. Effect of hot TCA versus cold TCA treatment on apparent leucine incorporation into protein

\begin{tabular}{llc}
\hline & \multicolumn{2}{c}{$\begin{array}{c}\text { Leucine incorporation rate (nmol } \\
\left.\mathrm{mg}^{-1} \mathrm{C}_{\text {org }} \mathrm{h}^{-1}\right)\end{array}$} \\
\cline { 2 - 3 } Treatment & \multicolumn{2}{c}{ Sediment } \\
\hline Hot TCA & Plant litter \\
\hline Cold TCA & $9.6 \pm 0.4$ & $8.6 \pm 1.5$ \\
\hline
\end{tabular}

Values are means of three replicates $\pm 1 \mathrm{SE}$.

${ }^{\mathrm{a}} p=0.50$.

${ }^{\mathrm{b}} p=0.97$. radioactivity incorporated at the high concentration of added leucine (cf. [2]).

Evidence from physiological studies with pure cultures indicates that fungi are capable of taking up leucine when concentrations are in the micromolar range. Horák [15] reports half-saturation constants $\left(K_{\mathrm{t}}\right)$ of 84 and $1400 \mu \mathrm{M}$ for two complementary transport systems in the yeast Saccharomyces cerevisiae, and half-saturation constants of 4 and $110-120 \mu \mathrm{M}$ for transport systems in Neurospora crassa. At least the high-affinity transport systems of $S$. cerevisiae $\left(K_{\mathrm{t}}=84 \mu \mathrm{M}\right)$ and those of $N$. crassa would thus allow significant leucine uptake at $50 \mu \mathrm{M}$. The question remains, however, whether fungi can also compete successfully for leucine when bacteria are present. The highaffinity transport system of $S$. cerevisiae $\left(K_{\mathrm{t}}=84 \mu \mathrm{M}\right)$ shows maximum uptake velocities $\left(v_{\max }\right)$ of $1 \mathrm{nmol} \mathrm{min}{ }^{-1}$ $\mathrm{mg}^{-1}$ fungal dry weight [15] and so would assimilate 0.37 $\mathrm{nmol} \mathrm{min}^{-1} \mathrm{mg}^{-1}$ at $50 \mu \mathrm{M}$. The high-affinity transport system of $N$. crassa $\left(K_{\mathrm{t}}=4 \mu \mathrm{M}\right)$ has a $v_{\max }$ of $0.1 \mathrm{nmol}$

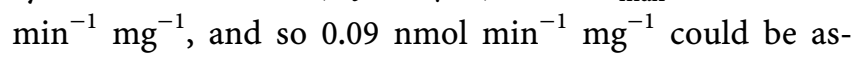
similated at $50 \mu \mathrm{M}$. In comparison, incorporation rates of leucine into bacteria in the present study translate to 7 $\mathrm{nmol} \mathrm{min}^{-1} \mathrm{mg}^{-1}$ bacterial dry weight, if an average bacterial carbon content of $1.5 \mathrm{mg} \mathrm{g}^{-1}$ plant litter carbon and a carbon to dry weight ratio of 0.45 is assumed [5]. Thus, in the experimental conditions of the present study (added leucine concentration of $50 \mu \mathrm{M}$ ), bacteria would take up leucine 19-65 times faster than fungi.

Although these scenarios may reflect the natural situation in freshwater wetlands only roughly, they give an idea of the potential magnitude of rates of fungal protein synthesis. If the kinetic parameters above are applicable, the fungi colonizing submerged plant litter would contribute equally to total leucine incorporation if their active biomass were 19-65 times that of bacteria. For many systems, including the sediments examined in the present study, it is therefore unlikely that fungi played a sub- 


\section{Prepare litter, sediment or epiphyton sample}

2

3

4

5

6

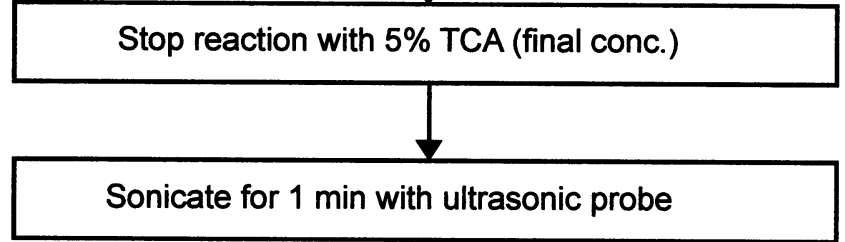

Filter supernatant through $0.2 \mu \mathrm{m}$ polycarbonate filter

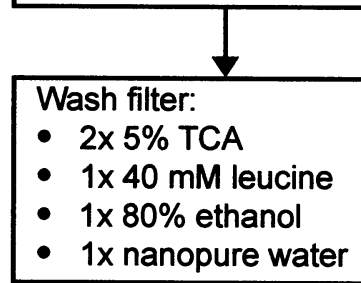

- $1 \times 80 \%$ ethanol
- $1 \times$ nanopure water

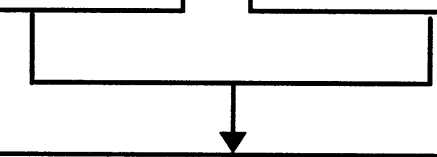

Add alkaline solution

7

8

Centrifuge at $14,000 \mathrm{~g}$ for $10 \mathrm{~min}$

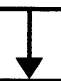

Add to $0.1-0.5 \mathrm{ml}$ aliquots $10 \mathrm{ml}$

Hionic Fluor ${ }^{\mathrm{TM}}$ and count radioactivity in scintillation counter

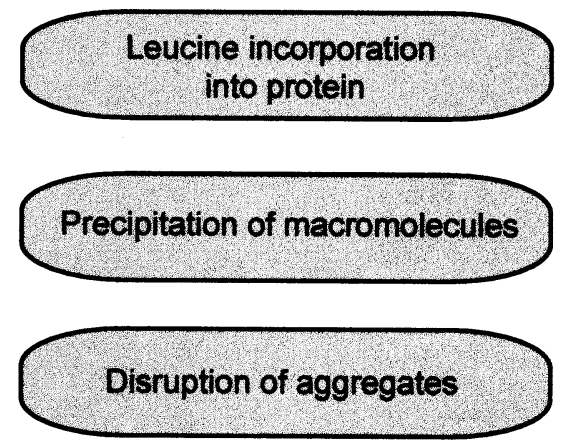

Separation of macromolecules from non-incorporated label

\section{Protein cleaning}

Combination of washed pellet and filter

\section{Protein extraction}

\section{Clarification of extract}

\section{Quantification of incorporated leucine}

Fig. 3. Proposed procedure for extracting radiolabeled protein from bacteria associated with decaying plant litter, sediment, and epiphyton. 
stantial part in leucine incorporation during short-term incubations. However, in submerged plant litter decaying in freshwaters, fungal biomass can indeed exceed bacterial biomass by a factor of 20 or more $[4,21,44]$ and so might contribute appreciably to total leucine incorporation. Consequently, the potential of leucine incorporation by eukaryotes cannot be ignored in these systems, even though direct measurements with the actetate-to-ergosterol method [14] suggest that fungal productivity associated with submerged plant litter in a littoral macrophyte stand is about one order of magnitude lower than that of bacteria [5].

In conclusion, the leucine method represents a useful tool for measuring bacterial production in littoral water, epiphytic biofilms, aerobic sediment, and, with some limitations, submerged plant litter. Saturation of leucine incorporation was achieved for all substrates, although micromolar concentrations were needed with sediment and plant litter samples. In general, the critical criterion of specificity for bacterial protein synthesis may still be met, but caution must be used when the active biomass of fungi exceeds that of the bacteria greatly.

\section{Acknowledgments}

We are grateful to Professors K.A. Kuehn, K. Suberkropp, J.V. Ward, and R.G. Wetzel, for discussion and constructive comments on a previous draft of the manuscript. We also thank Drs. C. Griebler, H. Fischer, A.K.T. Kirschner, and J. Marxsen for the exchange of ideas on several occasions. This study was partly supported by grants from the Swiss National Science Foundation (grant no. 3100-050439) and the Research Commission of the Swiss Federal Institute of Technology (ETH Zurich; grant no. 0-23010-00).

\section{References}

1. Azam F, Smith DC, Steward GF, Hagström A (1994) Bacteria-organic matter coupling and its significance for oceanic carbon cycling. Microb Ecol 28:167-179

2. Bååth E (2001) Estimation of fungal growth rates in soil using ${ }^{14} \mathrm{C}$-acetate incorporation into ergosterol. Soil Biol Biochem 33:2011-2018

3. Bååth E, Pettersson M, Söderberg K (2001) Adaptation of a rapid an economical microcentrifugation method to measure thymidine and leucine incorporation by soil bacteria. Soil Biol Biochem 33:1571-1574
4. Baldy V, Chauvet E, Charcosset J-Y, Gessner MO (2002) Microbial dynamics associated with leaves decomposing in the mainstem and floodplain pond of a large river. Aquat Microb Ecol 28:25-36

5. Buesing N (2002) Microbial productivity and organic matter flow in a littoral reed stand. Dissertation ETH No. 14667, Zurich, Switzerland

6. Buesing N, Gessner MO (2002) Comparison of detachment procedures for direct counts of bacteria associated with sediment particles, plant litter and epiphytic biofilms. Aquat Microb Ecol 27:29-36

7. Chin-Leo G, Kirchman DL (1988) Estimating bacterial production in marine waters from the simultaneous incorporation of thymidine and leucine. Appl Eviron Microbiol 54:1934-1939

8. Chin-Leo G (2002) Bacterial secondary productivity. In: CJ Hurst, RL Crawford, GR Knudsen, MJ McInerney, LD Stetzenbach (eds) Manual of Environmental Microbiology, 2nd ed. ASM Press, Washington, DC pp 354-363

9. Ducklow HW, Dickson M-L, Kirchman DL, Steward G, Orchardo J, Marra J, Azam F (2000) Constraining bacterial production, conversion efficiency and respiration in the Ross Sea, Antarctica, January-February, 1997. Deep-Sea Res II 47:3227-3247

10. Fischer H, Pusch M (1999) Use of the $\left[{ }^{14} \mathrm{C}\right]$ leucine incorporation technique to measure bacterial production in river sediments and the epiphyton. Appl Environ Microbiol 65:4411-4418

11. Fischer H, Pusch M (2001) Comparison of bacterial production in sediments, epiphyton and the pelagic zone of a lowland river. Freshwat Biol 46:1335-1348

12. Fuhrman JA, Azam F (1980) Bacterioplankton secondary production estimates for coastal waters of British-Columbia, Antarctica, and California. Appl Environ Microbiol 39:10851095

13. Furtado ALD, Casper P (2000) Different methods for extracting bacteria from freshwater sediment and a simple method to measure bacterial production in sediment samples. J Microbiol Methods 41:249-257

14. Gessner MO, Newell SY (2002) Biomass, growth rate, and production of filamentous fungi in plant litter. In: CJ Hurst, RL Crawford, GR Knudsen, MJ McInerney, LD Stetzenbach (eds) Manual of Environmental Microbiology, 2nd ed. ASM Press, Washington, DC pp 390-408

15. Horák J (1986) Amino acid transport in eucaryotic microorganisms. Biochim Biophys Acta 864:223-256

16. Jørgensen NOG (1992) Incorporation of $\left[{ }^{3} \mathrm{H}\right]$ leucine and $\left[{ }^{3} \mathrm{H}\right]$ valine into protein of freshwater bacteria: uptake kinetics and intracellular isotope dilution. Appl Environ Microbiol 58:3638-3646

17. Kairesalo T, Tuominen L, Hartikainen H, Rankinen K (1995) The role of bacteria in the nutrient exchange between sediment and water in a flow-through system. Microb Ecol 29:129-144

18. Kirchman DL, K'Nees E, Hodson R (1985) Leucine incorporation and its potential as a measure of protein synthesis 
by bacteria in natural aquatic systems. Appl Environ Microbiol 49:599-607

19. Kirschner AKT, Velimirov B (1999) Benthic bacterial secondary production measured via simultaneous ${ }^{3} \mathrm{H}$-thymidine and ${ }^{14} \mathrm{C}$-leucine incorporation, and its implication for the carbon cycle of a shallow macrophyte-dominated backwater system. Limnol Oceanogr 44:1871-1881

20. Kirschner AKT, Velimirov B (1999) Modification of the ${ }^{3} \mathrm{H}-$ leucine centrifugation method for determining bacterial protein synthesis in freshwater samples. Aquat Microb Ecol 17:201-206

21. Komínková D, Kuehn KA, Büsing N, Steiner D, Gessner MO (2000) Microbial biomass, growth, and respiration associated with submerged litter of Phragmites australis decomposing in a littoral reed stand of a large lake. Aquat Microb Ecol 22:271-282

22. Madigan MT, Martinko JM, Parker J (2002) Brock Biology of Microorganisms, $10^{\text {th }}$ ed. Prentice Hall, New Jerseypp 1104

23. Marxsen J (1996) Measurement of bacterial production in stream-bed sediments via leucine incorporation. FEMS Microbiol Ecol 21:313-325

24. Meyer-Reil L-A, Charfreitag O (1991) Observations on the microbial incorporation of thymidine and leucine in marine sediments. Kieler Meeresforschung 8:117-120

25. Michel PH, Bloem J (1993) Conversion factors for estimation of cell production rates of soil bacteria from $\left[{ }^{3} \mathrm{H}\right]$ thymidine and $\left[{ }^{3} \mathrm{H}\right]$ leucine incorporation. Soil Biol Biochem 25:943950

26. Moran MA, Hodson RE (1992) Contributions of three subsystems of a freshwater marsh to total bacterial secondary productivity. Microb Ecol 24:161-170

27. Munro HN, Fleck A (1966) The determination of nucleic acids. Meth Biochem Anal 14:113-176

28. Newell SY, Moran MA, Wicks R, Hodson RE (1995) Productivities of microbial decomposers during early stages of decomposition of leaves of a freshwater sedge. Freshwat Biol 34:135-148

29. Petit M, Servais P, Lavandier P (1999) Bacterial production measured by leucine and thymidine incorporation rates in French lakes. Freshwat Biol 42:513-524

30. Rausch T (1981) The estimation of micro-algal protein content and its meaning to the evaluation of algal biomass I. Comparison of methods for extracting protein. Hydrobiologia 78:237-251

31. Riemann B, Azam F (1992) Measurements of bacterial protein synthesis in aquatic environments by means of leucine incorporation. Mar Microb Food Webs 6:91-105
32. Riemann B, Bell RT (1990) Advances in estimating bacterial biomass and growth in aquatic systems. Arch Hydrobiol 118:385-402

33. Robarts RD, Zohary $\mathrm{T}$ (1993) Fact or fiction-bacterial growth rates and production as determined by [methyl- ${ }^{3} \mathrm{H}$ ]thymidine? Adv Microb Ecol 13:371-425

34. Scheidegger A, Stöckli A, Wüest A (1994) Einfluss der internen Sanierungsmassnahmen auf den Sauerstoffhaushalt im Hallwilersee. Wasser, Energie, Luft 86:126-131

35. Schmidt G, Thannhauser SJ (1945) A method for the determination of desoxyribonucleic acid, ribonucleic acid, and phosphoproteins in animal tissues. J Biol Chem 161:8389

36. Schneider WC (1945) Phosphorus compounds in animal tissues. 1. Extraction and estimation of desoxypentose nucleic acid and of pentose nucleic acid. J Biol Chem 161:293303

37. Sherr BF, Sherr EV, Andrew TL, Fallon RD, Newell SY (1986) Trophic interactions between heterotrophic protozoa and bacterioplankton in estuarine water analyzed with selective metabolic inhibitors. Mar Ecol Prog Ser 32:169-179

38. Simon M, Azam F (1989) Protein content and protein synthesis rates of planktonic marine bacteria. Mar Ecol Prog Ser 51:201-213

39. Simon M, Grossart H-P, Schweitzer B, Ploug H (2002) Microbial ecology of organic aggregates in aquatic ecosystems. Aquat Microb Ecol 28:175-211

40. Suberkropp K, Weyers H (1996) Application of fungal and bacterial production methodologies to decomposing leaves in streams. Appl Environ Microbiol 62:1610-1615

41. Thomaz SM, Wetzel RG (1995) $\left[{ }^{3}\right.$ H]Leucine incorporation methodology to estimate epiphytic bacterial biomass production. Microb Ecol 29:63-70

42. Tuominen L (1995) Comparison of leucine uptake methods and a thymidine incorporation method for measuring bacterial activity in sediment. J Microbiol Methods 24:125-134

43. Van Looij Q, Riemann B (1993) Measurements of bacterial production in coastal marine environments using leucine: application of a kinetic approach to correct for isotope dilution. Mar Ecol Prog Ser 102:97-104

44. Weyers HS, Suberkropp K (1996) Fungal and bacterial production during the breakdown of yellow poplar leaves in 2 streams. J N Am Benthol Soc 15:408-420

45. Wicks RJ, Robarts RD (1988) Ethanol extraction requirement for purification of protein labeled with $\left[{ }^{3} \mathrm{H}\right]$ leucine in aquatic bacterial production studies. Appl Environ Microbiol 54:3191-3193 